\title{
Influence of the selective laser sintering process parameters on the physical properties of spatial model of the ceramic implant
}

\author{
Wpływ parametrów procesu selektywnego spiekania laserowego \\ na właściwości fizyczne modelu przestrzennego implantu ceramicznego
}

\author{
BARBARA STANIEWICZ-BRUDNIK \\ ANDRZEJ STWORA \\ MAKGORZATA KAROLUS \\ GRZEGORZ SKRABALAK \\ ELŻBIETA BACZEK*
}

DOI: 10.17814/mechanik.2016.8-9.315

\begin{abstract}
Selective laser sintering (SLS) is a promising technique for modern materials preparation of complex shapes in one operation without any additional equipment. This technique allows production of ceramic implants at a preset porosity. Performed researches aimed at describing the effect of operating parameters of EOS EOSINT 250Xt machine on microstructure (XRD) and physical properties (apparent density, open porosity) of ceramic preliminary spatial models of implants built from submicrocrystalline sintered corundum and $99 \mathrm{~A}$ noble electrocorundum

KEYWORDS: SLS technique, ceramic implant, submicrocrystalline sintered corundum, 99A noble corundum, open porosity, apparent density
\end{abstract}

Selektywne spiekanie laserowe (SLS) jest obiecująca, nowoczesna techniką otrzymywania materiałów o skomplikowanych kształtach w jednej operacji technologicznej, bez wprowadzania dodatkowego oprzyrządowania. Technika ta pozwala na wytwarzanie implantów ceramicznych o zaprogramowanej dużej porowatości. Badano wpływ parametrów pracy urządzenia EOS-EOSINT 250Xt na mikrostrukturę (XRD) i właściwości fizyczne (gęstość pozorną, porowatość otwarta) kształtek ceramicznych wstępnych modeli przestrzennych implantów z submikrokrystalicznego korundu spiekanego i elektrokorundu szlachetnego $99 \mathrm{~A}$

SŁOWA KLUCZOWE: technika SLS, implant ceramiczny, submikrokrystaliczny korund spiekany, elektrokorund szlachetny 99A, porowatość otwarta, gęstość pozorna

Selective laser sintering (SLS) is one of the methods of additive manufacturing of components, prototypes and tools. The process involves melting and the merging the layers of powder with a laser beam. Majority of commercially available SLS systems use the radiation source in the infrared range: the $\mathrm{CO}_{2}$ laser $(10.6 \mu \mathrm{m})$ or $\mathrm{Nd}$ : YAG, fiber lasers $(1,06 \mu \mathrm{m})$. The laser beam melts the powder surface in accordance with the previously programmed and properly configured information on the successive layers of the cross-sectional image of the spatial object.

The selection of appropriate parameters of the laser beam (beam power, the scanning speed, distance between lines thickness of layers) allows for the sintering (melting) at specific areas of the powder particles [1, 2].

* Dr inż. Barbara Staniewicz-Brudnik prof. IZTW (bbrudnik@ios.krakow. pl), mgr inż. Andrzej Stwora, dr hab. Małgorzata Karolus, dr inż. Grzegorz Skrabalak, mgr inż. Elżbieta Bączek - IZTW Kraków
The SLS technology provides a flexible and inexpensive production of small series and individual components. The technique of selective laser sintering of ceramic powders are rarely used due to the low availability of laser equipment for sintering ceramics. The Institute of Advanced Manufacturing Technology has EOS EOSINT 250Xt machine, which can be used for sintering of free-form ceramic components (Fig. 1).

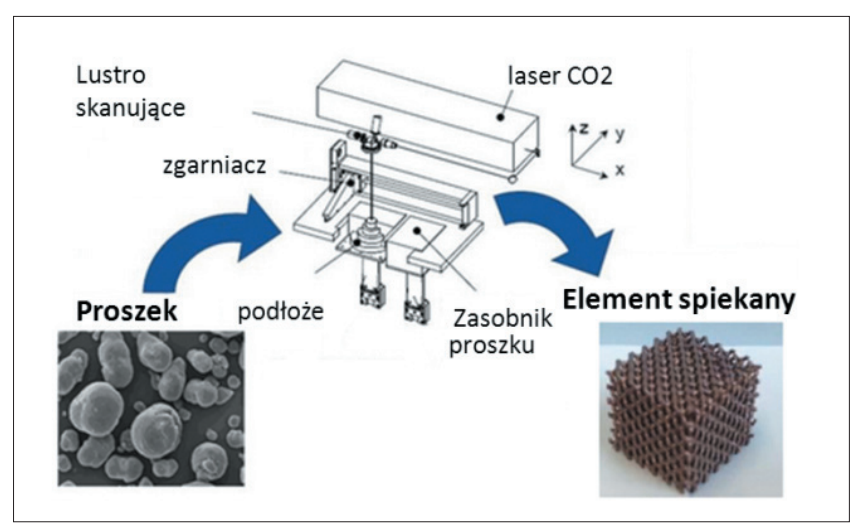

Fig. 1. Scheme of the SLS process

Selective laser sintering is an example of technology appreciated after 30 years of its invention. The first patent for a system of forming a layered object was reported by Ross Hausholder in 1979 (Patent US4247508A). However, it wasn't commercialized due to lack of funds. Regardless of Ross Hausholder'a in 1981 by Carl Decard developed the concept of building a similar machine parts using selective laser sintering. The first commercial unit was developed in the company at Desk Top Manufacturing (DTM) in 1989. Currently, the market leaders of the SLS systems are: 3D Systems, EOS, Phoenix Systems [3].

\section{Methodology of research and discussion of results}

The initial spatial models (shapes $10 \times 10 \mathrm{~mm}$ ) were sintered of submicrocrystaline sintered corundum of F80 granulation $(180 \div 212 \mu \mathrm{m})$ long milled in a ball mill Pullverisette 6 devices, later on sieved though a mesh $40 \mu \mathrm{m}$ and non-milled submicrosrystalline sintered corundum of F80 granulation and 99A nobel electrocorundum of F120 granulation $(95 \div 126 \mu \mathrm{m})$. 
For the needs of SLS process using EOS EOSINT 250Xt following parameters were used: scanning speed of $100 \mathrm{~mm} / \mathrm{sec}$, layer thickness $0.1 \mathrm{~mm}$, hatch space of $0.1 \mathrm{~mm}$ and laser power was changed in the range of $25 \div 45 \%$ of maximum power.

Diffractometry (XRD) analysis of sinters (Fig. 2) allowed to determine the phase composition, crystallite size and unit cell parameters of the materials were obtained. Also determined apparent density, open porosity and density of the skeleton for a noble electrocorundum 99A were measured. Initially, at the maximum parameters of operation, sintering of fine submicrocrystalline sintered corundum gave no positive results. Due to the fineness of the grains of sintered alumina, when too high laser power was used, powder seeds were ejected from the powder bed surface out of the laser influence zone.

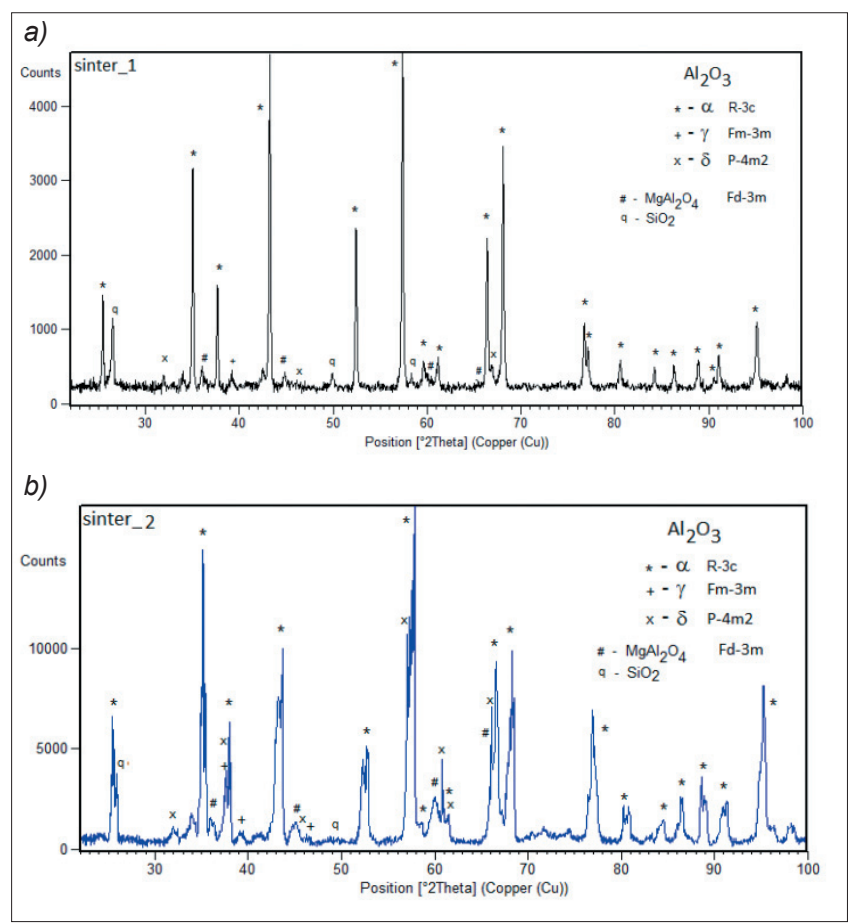

Fig. 2. Diffraction patterns of samples obtained from unmilled submicrocrystalline sintered corundum $(a)$, milled $(b)$

There was no adhesion to the substrate (titanium plate) for particles of submicrocrystalline sintered corundum, lowering the laser power to a range of $25 \div 45 \%$ of maximum power allowed to obtain sintered moldings, the greater the grain size (F80, F120), the better they formed the fittings. In case of samples obtained from milled grains of the sintered corundum surface of sintered sample had deformed shapes.

In the X-ray diffraction spectra (Fig. 2) in all three sinter: unmilled and milled submicrosrystalline sintered corundum and noble electrocorundum presence of $\alpha, \gamma, \delta-\mathrm{Al}_{2} \mathrm{O}_{3}$ and $\mathrm{Mg}_{0.4} \mathrm{Al}_{2.4} \mathrm{O}_{4}$ non-equilibrium phase (spinel $\mathrm{MgAl}_{2} \mathrm{O}_{4}$ ) were identified. The phase composition of the samples are shown in Table I. The crystallite size were varied from 15.8 to $100 \mathrm{~nm}$.

Samples of noble electrocorundum were sintered at different laser power $(25,30,35,40$ and $45 \%$ of maximum power). The open porosity, the density of the skeleton and apparent density were measured using hydrostatic measurement method (EN 623-2). The open porosity decreased with increasing laser power from value of $38 \%$, reaching minimum $(20 \%)$ at $40 \%$ of maximum power, then increased to $25 \%$ at $45 \%$ power (Table II).
TABLE I. Phase analysis of sinter

\begin{tabular}{|c|c|c|c|c|}
\hline Sample & Phase & $\begin{array}{l}\text { Cell unit/pa- } \\
\text { rameters } \\
\text { a/b/c, nm }\end{array}$ & Amount, \% & $\begin{array}{l}\text { Crystallite } \\
\text { size } D, \mathrm{~nm}\end{array}$ \\
\hline sinter_1 & $\begin{array}{c}\mathrm{Al}_{2} \mathrm{O}_{3} \alpha \\
\mathrm{Al}_{2} \mathrm{O}_{3} \gamma \\
\mathrm{Al}_{2} \mathrm{O}_{3} \delta \\
\mathrm{MgAl}_{2} \mathrm{O}_{4} \\
\mathrm{SiO}_{2}\end{array}$ & $\begin{array}{c}0,47590 / \\
1,29926 \\
0,39415 \\
0,59543 / \\
2,35889 \\
0,83247\end{array}$ & $\begin{array}{l}84 \\
\\
3 \\
3 \\
\\
\\
3 \\
7\end{array}$ & 51,9 \\
\hline sinter_2 & $\begin{array}{c}\mathrm{Al}_{2} \mathrm{O}_{3} \alpha \\
\mathrm{Al}_{2} \mathrm{O}_{3} \gamma \\
\mathrm{Al}_{2} \mathrm{O}_{3} \delta \\
\mathrm{MgAl}_{2} \mathrm{O}_{4} \\
\mathrm{SiO}_{2}\end{array}$ & $\begin{array}{c}0,47630 / \\
1,30019 \\
0,45695 \\
0,54466 / \\
2,55181 \\
0,80069\end{array}$ & $\begin{array}{l}84 \\
3 \\
3 \\
\\
4 \\
6 \\
\end{array}$ & 15,8 \\
\hline sinter_3 & $\begin{array}{l}\mathrm{Al}_{2} \mathrm{O}_{3} \alpha \\
\mathrm{Al}_{2} \mathrm{O}_{3} \delta \\
\mathrm{MgAl}_{2} \mathrm{O}_{4}\end{array}$ & $\begin{array}{c}0,47589 / \\
1,29979 \\
0,55936 / \\
2,36479 \\
0,79220\end{array}$ & $\begin{array}{l}91 \\
6 \\
3\end{array}$ & $>100$ \\
\hline
\end{tabular}

TABLE II. Effects of laser power on the open porosity and apparent density

\begin{tabular}{|c|c|c|}
\hline$\%$ max power & Open porosity, \% & Apparent density, $\mathrm{g} / \mathrm{cm}^{3}$ \\
\hline 25 & 37,982 & 2,43 \\
\hline 30 & 35,729 & 2,53 \\
\hline 35 & 32,577 & 2,64 \\
\hline 40 & 20,111 & 3,17 \\
\hline 45 & 24,977 & 2,96 \\
\hline
\end{tabular}

\section{Resume}

Selective laser sintering is a promising technique that allows to build components of corundum ceramics at preset high porosity. Fragmentation of grains of submicrocrystalline sintered corundum did not allow to obtain samples of the assumed shape, only increasing the grain size $(>100 \mu \mathrm{m})$ enabled to receive samples of the desired shape. The open porosity of the prepared samples, reached a minimum for $40 \%$ of the maximum power of the laser beam.

The research was carried out in the frame of Statutory Work of The Institute of Advanced Manufacturing Technology - DS.15-1.5.1

\section{LITERATURE}

1. Bertrand $\mathrm{Ph}$. et al. "Ceramic components manufacturing by selective laser sintering". Applied Surface Science. 254 (2013): pp. 610 614

2. Niu F. et al. "Effect of second-phase doping on laser deposited $\mathrm{Al}_{2} \mathrm{O}_{3}$

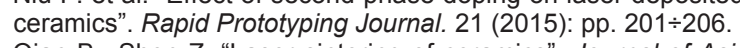

3. Qian B., Shen Z. "Laser sintering of ceramics". Journal of Asian Ceramic Society. 1 (2013): pp. 315 $\div 321$.

4. Staniewicz-Brudnik B. et al. "The technique of selective laser sintering (SLS) in the design high-porous ceramic implants". Mechanik. 5-6 (2016): pp. $540 \div 541$.

5. PN-EN 623-2:2001 Techniczna ceramika zaawansowana - Ceramika monolityczna - Właściwości ogólne i strukturalne - Część 2: Oznaczanie gęstości i porowatości. 